\title{
SEARCHING FOR NEW DIAMOND DEPOSITS IN WESTERN LIBERIA
}

\author{
Dyakonov DB ${ }^{1}$, Garanin VK ${ }^{2}$, Garanin*KV ${ }^{2}$, Bushueva EB ${ }^{2}$, Enalieva MA $^{2}$, Vvedensky ES $^{3}$ \\ WAGS, Conakry, Guinea ${ }^{1}$; M.V. Lomonosov Moscow State University, Moscow Russia ${ }^{2}$; Lofa Minerals Corp ${ }^{3}$
}

\section{INTRODUCTION}

The problems and criteria searching works for new diamond deposits in Western Liberia are considered. Diamonds and other kimberlitic indicator minerals (KIM) discovered in the searching areas Yambassen and Kumgbo comprehensively studied. These minerals are associated with unknown kimberlitic occurrences. KIM's morphology and chemical composition were investigated by optical and scanning electron microscopy, and microprobe technique.

The electron-probe microanalysis results of ilmenite and garnet were interpreted using the appropriate chemical-genetic classifications (Garanin et al., 1991). The wide presence of different non-kimberlitic minerals (spinel, corundum, zircon, etc.) was discovered in searching areas.

\section{INVESTIGATION METHODS}

Diamonds investigation were realized with using optical microscopy technique for their morphological study (identification of form, color, surface characteristics, internal structure, etc.).

Garnets and ilmenites chemical composition and morphology were studied with using scanning electrom microscopy and microprobe analyze techniques.

\section{RESULTS}

Besides typical KIMs (diamonds, piropes and

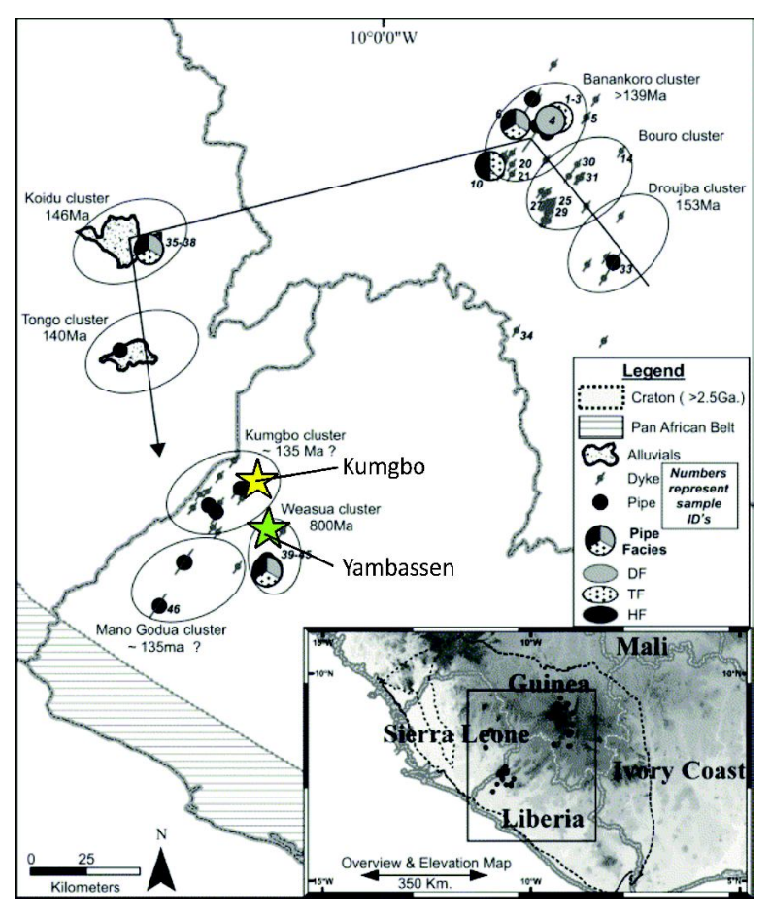

Fig. 1. Yambassen and Kumgbo prospecting territories on a map of the area showing the distribution of the kimberlites, intrusion types, facies classifications and ages. The arrow indicates the interpreted "hot spot track" or the direction of continental movement between about 153 and $140 \mathrm{Ma}$ (after Skinner et. al., 2004).

Mg-ilmenites) a wide range of minerals genetically connected with different basement rocks (spinel, corundum, zircon, etc.) were discovered in samples from sediment in prospecting areas. Non-kimberlitic minerals can be used as characteristics of the local depositional collectors and for paleoreconstructions.

666 ilmenites (size $+0.3-0.7 \mathrm{~mm}$ ) from Yambassen prospecting area and 28 diamond 


\section{0 $^{\text {th }}$ International Kimberlite Conference, Bangalore - 2012}

crystals (weight $0.08-10.0$ carats), 114 garnets (+1-4 mm), and 341 ilmenites (size $+0.3-0.7 \mathrm{~mm}$ ) from Kumgbo prospecting area were analyzed.

It was identified that KIMs from Kumgbo prospecting area have higher distribution and bigger size than KIMS from samples collected in Yambassen prospecting area.

KIMs from the Yambassen prospecting territory are represented only Mg-ilmenites in the $-0.7 \mathrm{~mm}$ size class. Small size of $\mathrm{Mg}$-ilmenite grains indicates a long distance of primary sources (kimberlites) from the sampled area. Estimating the grains dimension and their degree of mechanical treatment it possible to conclude that the kimberlites located within a few tens of kilometers from the prospecting territory.

Note the absence of diamonds discoveries in samples collected from sediment rocks of the Yambassean prospecting area. Perhaps according the intensive geological processing of sediment, which overlying by thin layer on the craton, small diamonds were either transported downstream, or destroyed, resulting in the search area remained basically the rarely presented large stones with a weight over 0.3 carats and requiring a significant amount of host rocks processing.

It should be noted that $8 \%$ of all studied ilmenites refer to the diamondiferous paragenesis Mg-ilmenites. $6 \%$ of ilmenites have nonkimberlitic genesis. When comparing different groups of ilmenites their contrasting differences between samples are not observed, but the chemistry of each sample ilmenites has individual characteristics. In some samples revealed a higher proportion of picroilmenite with high Cr-content. As it shown in Fig. 2 the Yambassen ilmenites chemical composition peculiarities predicted a detection of two primary sources (kimberlite bodies). High-chromium Mg-ilmenites prevalent in industrial-diamondiferous kimberlites in South Africa, Yakutian and Arkhangelsk kimberlite provinces were not found. Therefore at present stage of prospecting works it possible to conclude
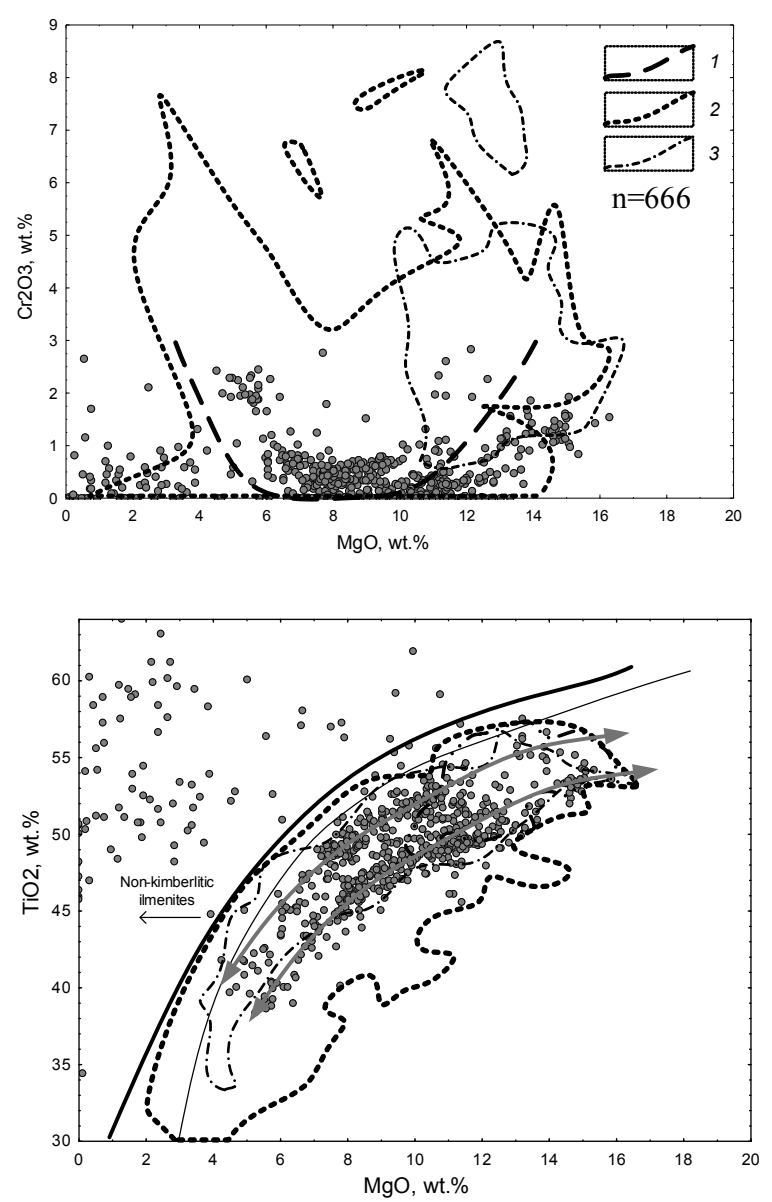

Fig. 2. Yambassen prospecting area ilmenites chemical composition in coordinates $\mathrm{MgO}-\mathrm{Cr}_{2} \mathrm{O}_{3}$ (above) è $\mathrm{MgO}-\mathrm{TiO}_{2}$ (below). 1 - trend of chemical composition for ilmenites from Lesoto and Western African kimberlites (Haggerty, 1975); 2 - Malo-Botuobinsky area (Yakutian province, Russia) ilmenites chemical composition field; 3 - V. Grib diamond deposit (Archangelsk province, Russia) ilmenites chemical composition field. Thickened line in Fig. B is a border for kimberlitic and non-kimberlitic ilmenites from different World kimberlite provinces, thin line is a border of ilmenites from South African kimberlites according B.A. Wyatt et al (2004). Arrows show two trends of ilmenites chemical composition variation, $\mathrm{n}-$ analyzes quantity.

that unknown kimberlites have lowdiamondiferous potential.

Diamonds, piropes and Mg-Ilmenites were discovered among KIMs from the samples collected in Kumgbo prospecting area.

The diamonds have kimberlite genesis, presented by big crystals (up to 10 carats) and 


\section{0 $^{\text {th }}$ International Kimberlite Conference, Bangalore - 2012}

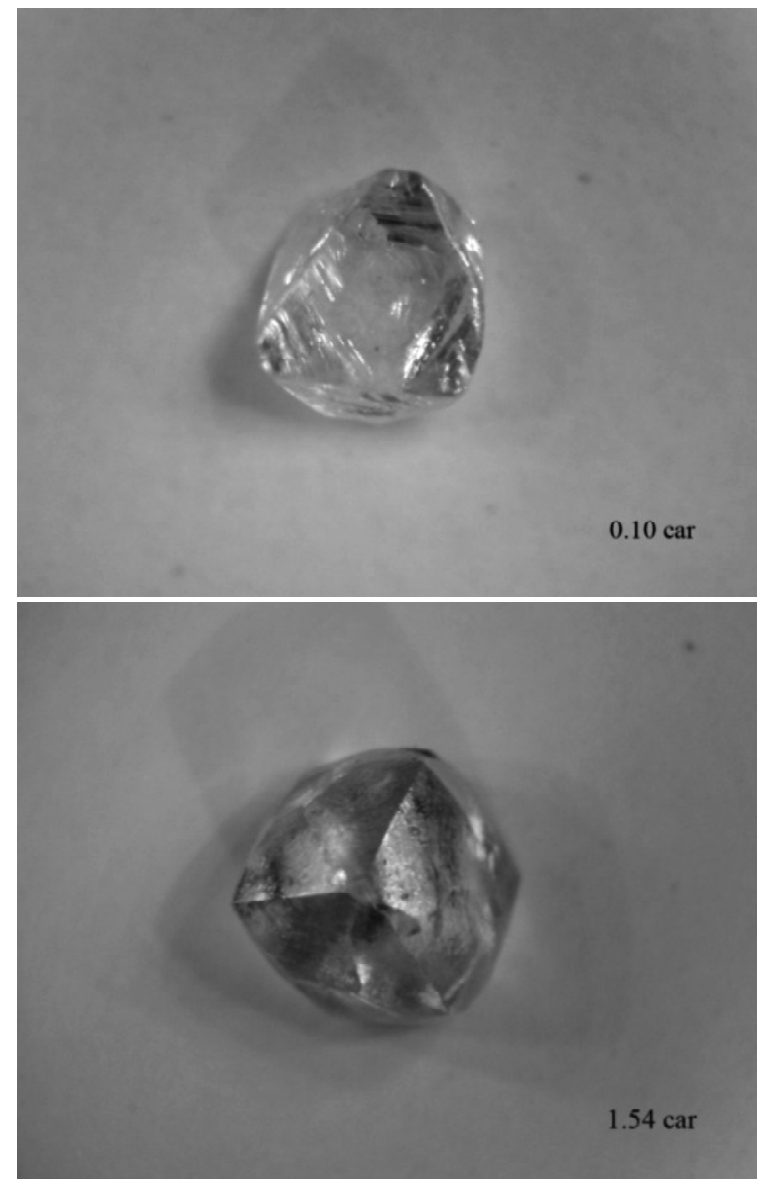

Fig. 3 Diamonds from Kumgbo prospecting territory: 0.1 carat octahedron with "rounded" facets (left) and 1.54 carat dodecahedron significantly compressed axially L3, with moderate mechanical treatment rate and facets

show a high quality (Fig. 3). There were mainly dodecahedrons (17 crystals) with lower octahedron proportion ( 7 crystals), and two diamond chips among studied diamonds. 13 diamonds did not content inclusions. 2 diamonds are black as many numerous small black inclusions were discovered. The chemical composition of inclusions was not studied yet. Diamond has lower mechanical treatment grade, only 6 crystals has facets attrition.

Pyropes from Kumgbo prospecting territory characterized by the middle size (1-2 mm). According their chemical composition most of them similar to pyrope from kimberlite. Wide presence of piropes from ilmenite ultramafic rocks and the presence of garnet from Low-chromium lherzolites are significant part of Kumgbo garnets (Fig. 4). Only three diamond paragenesis pyropes were discovered which responsible by its chemical composition to high-chromium and low-calcium pyrope from high-diamondiferous dunites and harzburgites. Characteristics of the chemical composition of garnets plot Kumgbo not suggest a high diamondiferous kimberlites of the composition of which they were made in the sedimentary sequence.

Garnet chemical composition features are not allowed to suggest high diamond grade for kimbelites which were the primary sources and from where studied piropes were eroded and deposited later in sediment.

Ilmenites from Kumgbo prospecting area are represented by different size classes. Ilmenites have bigger size and lower mechanical treatment degree compare to ilmenites from Yambassen prospectins area. Note that the previously studied ilmenite megacrysts from Kumgbo prospecting area had size up to $2 \mathrm{~cm}$ and characterized by higher $\mathrm{Cr}, \mathrm{Mg}$, Ti concentrations corresponding Mg-ilmenite from kimberlites (Dyakonov et al.,

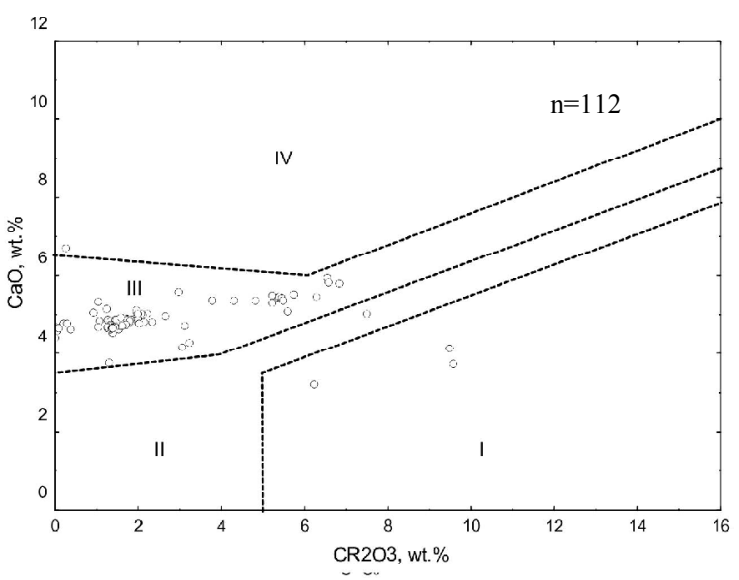

Fig. 4. Kumgbo prospecting area garnets (piropes) chemical composition in coordinates $\mathrm{Cr}_{2} \mathrm{O}_{3}-\mathrm{CaO}$. I - garnet inclusions in diamond, garnet from diamondiferous dunites and harzburgites, II garnet from dunites and harzburgites, III - garnet from lherzolites, IV - garnet verlites (Sobolev, 1974) 

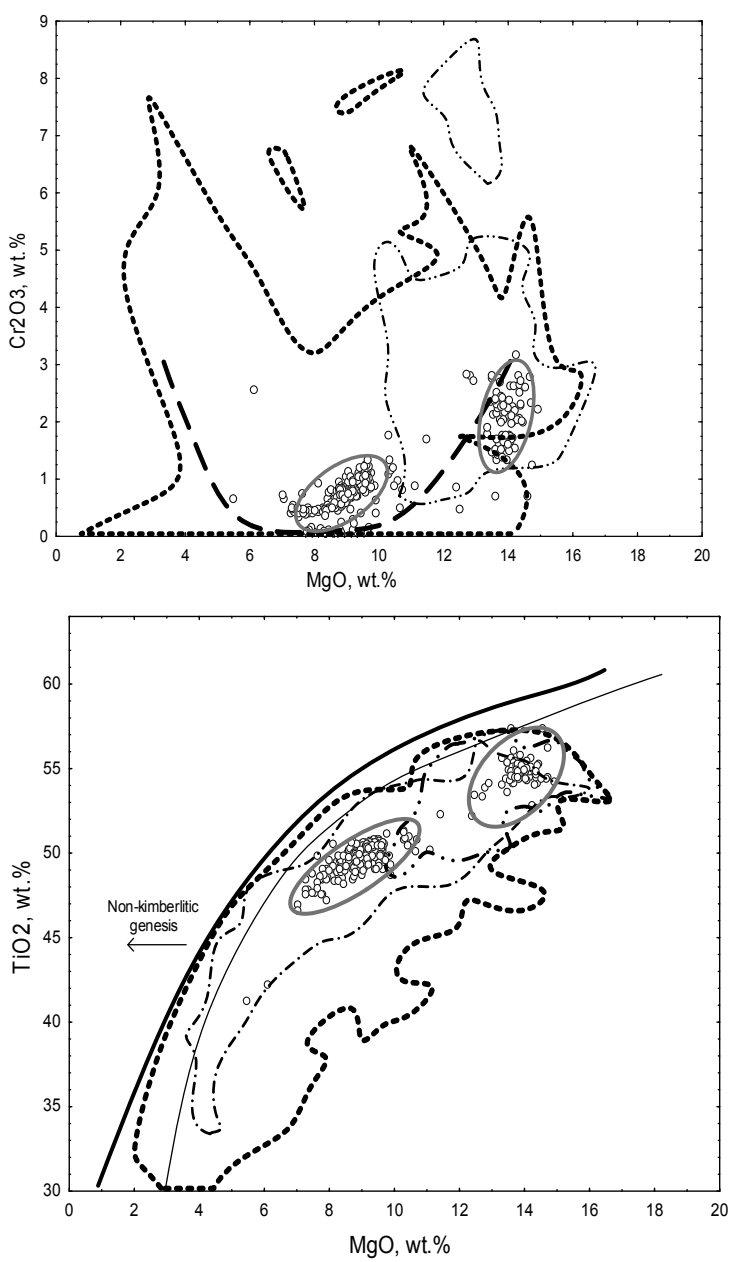

Fig. 5. Kumgbo prospecting area ilmenites chemical composition in coordinates $\mathrm{MgO}-\mathrm{Cr}_{2} \mathrm{O}_{3}$ (above) è $\mathrm{MgO}-\mathrm{TiO}_{2}$ (below). Conventional symbols see in Fig. 2

2010). The size and morphology of such megacrysts can predict the kimberlite bodies presence close proximity to the sampled area. The same for studied ilmenites we found an increased proportion $\mathrm{Mg}$-ilmenite with higher $\mathrm{Cr}$ concentrations compare with Mg-ilmenite from Yambassen prospectins area (Fig. 5). These Mgilmenites are typical for industrial diamondiferous kimberlites in South Africa, Yakutian and Arkhangelsk provinces. As a result of our research the chemical composition of ilmenites it was found that they have probably at least two primary sources (kimberlite bodies), one of which is characterized by increased diamond grade.

\section{CONCLUSION}

KIM (especially diamonds and pyropes) extracted from the Kumgbo area samples have more common distribution and a biggerr size compare to the KIM extracted from the Yambassen samples.

KIMs from the Yambassen area are presented only by ilmenites with size $-0.7 \mathrm{~mm}$. Such size, high abrasion and sorting degree indicate the long distance between their primary sources (kimberlites) location and the searching area. It was concluded the primary source is located not closer than several tens kilometers. Discovery of two primary KIMs' sources (kimberlites) prognosed after analyzing chemical composition of ilmenites from the Yambassen area. High-chromium picroilmenite prevalent in industrial diamondiferous kimberlites from South Africa, Arkhangelsk and Yakutsk provinces were not found. It does not give a possibility to prognose a discovery of industrial diamondiferous kimberlites within the boundaries of Yambassen area and several tens kilometers to the North from that concession.

Diamonds, pyropes and picroilmenites were discovered on the Kumgbo area territory. Diamonds have kimberlitic genesis, presented by high quality large crystals (up to 10 carats). Pyropes are characterized by average size 1-2 mm. Their similar to pyropes from kimberlites was identified after analyzing their chemical composition. Wide presence of garnet from ilmenite ultrabasites and low-chromium garnets from lherzolites was found. However, features of the garnets chemical composition from the Kumgbo area do not suggest a high diamond content in their primary source. Ilmenites presented by different size classes (up to $2 \mathrm{~cm}$ ), with larger size and lower abrasion degree compare to the ilmenites from Yambassen area. 
The size and morphology of ilmenite megacrysts assume the presence of kimberlite bodies nearby from the Kumgbo area. High proportion of picroilmenites with higher Cr-concentrations was found compare with picroilmenites from the Yambassen area. These ilmenites are typical for industrial diamondiferous kimberlites from South African, Arkhangelsk and Yakutian provinces. The study of the ilmenites chemical composition establishes at least two primary sources of these ilmenites, one of which is characterized by high predictive diamond grade.

Therefore a discovery of new diamondiferous objects and clusters are prognosing to North from searching areas based on a water drainage system direction. Presented results can be effectively applied in the further prospecting works for diamond deposits in the region and other areas of West Africa.

\section{References}

Dyakonov D.B., Garanin V.K., Garanin K.V., Enalieva M.A., Yapaskurt V.O. Mycrocrystalline ilmenite from Kumgbo (Liberia) and Lunda Norte (Angola) prospecting. Geology and exploration. 2010. ${ }^{1} 4$. P. $41-49$

Garanin V.K., Kudryavtseva G.P., Marfunin A.S. Inclusions in diamonds and diamondiferous rocks. Moscow. Moscow state university publishing house. 1991.350 p. In Russian

Skinner E.M.W., Apter D.B., Morelli C. and Smithson N.K. Kimberlites of the Man craton, West Africa. Lithos. 77. 2004. P. 233-260

Sobolev N.V. Hypogene inclusions in kimberlites and problem of Upper Mantle composition. Novosibirsk: Nauka. 1974. 264 p. In Russian 